\title{
Morocco's External Performance: An Empirical Assessment of Export Competitiveness Determinants
}

\section{Sara Labrar ( $\sim$ labrarsara@gmail.com )}

Mohammed V Agdal University: Universite Mohammed V de Rabat

\section{Adil Elmarhoum}

Mohammed V Agdal University: Universite Mohammed V de Rabat

\section{Research}

Keywords: Competitiveness, VECM model, exports, Armington, Morocco

Posted Date: October 9th, 2020

DOI: https://doi.org/10.21203/rs.3.rs-88689/v1

License: (c) (1) This work is licensed under a Creative Commons Attribution 4.0 International License.

Read Full License 


\section{Morocco's external performance: An empirical assessment of export competitiveness determinants}

\section{SARA LABRAR \& PROF. ADIL EL MARHOUM}

Laboratory of Applied Economics, University Mohammed V Rabat

Corresponding author’s e-mail address : labrarsara@gmail.com \& adil.elmarhoum@gmail.com 


\title{
Morocco's external performance: An empirical assessment of export competitiveness determinants
}

\author{
SARA LABRAR, ADIL EL MARHOUM
}

\begin{abstract}
The objective of this article is to study the external competitiveness of Morocco. To do so, we first make a sectoral analysis of Moroccan international trade. This analysis reveals the sectors and products in which Morocco should specialize, as well as the products in which Morocco has a strong export potential. Then, we study the impact of the introduction of price and cost competitiveness indicators in the export's equations of Armington (1969). Using a Vector Error Correction Model (VECM) estimated over the period 1988-2017. The principal results confirm that Moroccan external competitiveness can't be measured only by the price factor. We also show that the competitiveness is also reflected with other factors like cost of production and quality.
\end{abstract}

JEL Classification : C22, F14, F13, O55

Keywords: Competitiveness, VECM model, exports, Armington, Morocco.

Résumé - Cet article s'inscrit dans le cadre d'une étude sur la compétitivité extérieure marocaine. Pour ce faire, nous procédons tout d'abord à une analyse sectorielle du commerce extérieur marocain. L'objectif est de renseigner sur les secteurs et les produits dont le Maroc doit se spécialiser, ainsi que les produits dans lesquels le Maroc dispose d'un fort potentiel d'exportation. Ensuite, nous étudions l'impact de l'introduction des indicateurs de la compétitivité prix et coût dans les équations d'exportation tirées du modèle d'Armington (1969). En s'appuyant sur un modèle à correction d'erreur (MCE) estimé sur la période 19882017, les principaux résultats confirment que la compétitivité extérieure marocaine ne peut se résumer au seul facteur prix. Nous montrons, en outre, que la prise en compte d'autres facteurs de coût et de qualité permet une meilleure modélisation des équations d'exportation.

Mots clés : Compétitivité, modèle VECM, exportations, Armington, Maroc. 


\section{INTRODUCTION}

Today, globalization, the surge in international trade flows and the emergence of new challengers highlight the inequalities in economic development among countries. As a result, countries are forced to adopt new production strategies to cope with the impact of low-cost competitors and stand out through highly innovative activities. National competitiveness is at the core of this debate, so that to remain competitive, the economy must be able to maintain market share in the international market in the face of foreign competition.

In this context, in order to enhance competitiveness and market share abroad, Morocco has adopted a series of measures, possibly by opening up the international market to initiate the structural transformation of its economy. Several sector strategies have been adopted, the impact of which is reflected in the emergence of new growth drivers in industries with high export value added, shifting to high-end markets and positioning as a quality advantage.

It therefore appears that, despite the trend of increasing exports and the efforts made in international trade, Morocco is still suffering from a chronic trade deficit, given the importance of imports.

In particular, this work aims to explore the evolution of Moroccan exports in connection with the new challenges of globalization. That is why we propose to examine the sensitivity of Moroccan exports to the criteria characterizing competitiveness. The following question arises: "What effect do competitiveness factors have on Morocco's export performance? ».

On the other hand, international competition is also associated with challenges related to the restructuring of the world market in favor of new competitors and the reallocation of production resources that hit major holders and cause losses to some of them ${ }^{1}$. In other words, the question is: «How has international competitive pressure changed the composition of the Moroccan export? ».

This paper is organized as follows, the first part introduces a literature review on the competitiveness of nations, the second part presents a sectoral analysis to discover sectors and products that Morocco must specialize in. The last part introduces the results and main conclusions of econometric research.

${ }^{1}$ Cyrielle Gaglio (2017), "Compétitivité, sophistication et espace-produit. Une application aux exportations françaises". Economies et finances. Thèse de doctorat. Université Côte d'Azur. 


\section{LITERATURE REVIEW}

Based on the globalization phenomenon, which is particularly characterized by the opening of trade, the intensification of world trade flows, the constant change in the competitive environment, and the acceleration of lifestyles and consumption, we think it is useful to return to the main theoretical basis of competitiveness of countries. Indeed, some countries seem to benefit greatly from globalization. On the other hand, it seems that other countries are doing better than the rest in international trade. This globalization context does not pose the same challenges for developed countries as for developing countries: while the former are trying to effectively change their position in the face of growing competitive pressure, the latter are now intending to find a place on the international scene next to established leaders. Indeed, each country has developed its own economic policy to promote entrepreneur's efforts to find products suitable for export, and thus change the portfolio of exported products in favor of those with high potential. This means that no unified policy applies to every country.

The first part reviews economic literature from the 1980s to the present day regarding the competitiveness of countries, highlighting the unique context of current globalization. Although this concept has become ubiquitous in economic debates. However, it lacks a strict definition and a solid theoretical anchor.

Basically, the theory of comparative advantages (Ricardo, 1817) suggests that two countries participating in a joint exchange flow do not compete with each other because their profits are not to the detriment of others to the extent that international exchange brings mutual benefits between different stakeholders. Whether from the perspective of absolute advantage theory or from the perspective of comparative advantage theory, the country's specialization mechanism is crucial to international trade. Whether from the perspective of absolute advantage theory or from the perspective of comparative advantage theory, the country's specialization mechanism is crucial to international trade. Indeed, under the first theory, countries are strongly encouraged to participate in trade, so as long as there is an absolute advantage in the production of one or more commodities, Otherwise, the country seems forced to be self-sufficient. According to the second theory, compared with trading partners, countries are more likely to focus on the production of goods that they have an advantage. Despite the static nature of absolute advantage and comparative advantage, Ricard's theory is still the main reference for international trade flows between countries.

Recently, "New Theory of International Trade" (Krugman, 1981; 1991; Melitz, 2003; Baldwin and Okubo, 2006; Ottaviano, 2011) $)^{2}$ undermines this theoretical consensus, stating that international openness or regional integration may trigger agglomeration processes with winning regions and losers (Krugman, 1991). In addition, this theoretical consensus relating to the non-competition of territories is opposed by economic policy practice, which puts the concept of competitiveness at the core of its system. Therefore, a paradox exists both within theory and between theory and practice.

In addition to the new theory of international trade, Hausmann and Rodrik (2003) proposed a new concept of the national economic development process based on the self-discovery mechanism, that is, countries have discovered the products for which they will be performant in the long run. They believe that the success of the country 's economic development is not only a question of market discipline that encourages efficiency, but also an issue of industrial policy and active promotion of exports, which is conducive to the redistribution of production resources and the discovery of products with high growth potential.

To be competitive means to face competition. However, competitiveness is not understood in the same way according to the scale of the analysis to which we refer: the competitiveness of enterprises, industries or countries. Below, we will discuss the details of each of these three analysis scales from the perspective of competitiveness.

First, at the company level, competitiveness refers to the ability of each of them to gain and maintain market share, but also to regain market share of its main competitors, whether on the national market.

\footnotetext{
${ }^{2}$ Articles Cited in Chiappini, R. (2011). "Comment mesurer la compétitivité structurelle des pays dans les équations d'exportation ?", L'Actualité économique, 31-57.
} 
and / or international. Therefore, the company adapts immediately, more or less, to its competitive environment through non-price competitiveness or structural competitiveness (this depends on the company's ability to differentiate it from its competitors by formulating product differentiation strategies in terms of quality, for example), or through price competitiveness (based on the company's ability to respond to domestic or international competition by proposing a similar product price reduction policy). This traditional subdivision of competitiveness of companies between structural competitiveness on the one hand and price competitiveness on the other, constitutes a strong consensus in economic thought. In addition, uncompetitive company, that is, companies that cannot respond quickly to strong or even unexpected competitive pressures, will withdraw from national or international markets and be replaced by another, more competitive company ${ }^{3}$.

Secondly, at the industry level, competitiveness also refers to the sum of the individual competitiveness of the companies that make up an industry, as well as the redistribution of production resources among companies that belong to the same industry.

At the national level, competitiveness is more complex for economists to define. In fact, the latter seems reluctant to the concept of national competitiveness. Moreover, this reluctance is not unfounded: we present the following two main arguments behind this suspicion: The first argument reminds us that economic thought is based on the general conviction that countries are not competing with each other. This conviction is especially based on comparative advantage theory. By extending the theory of the absolute benefits of Smith's competition (1776), countries have a strong incentive to participate in trade, and thus to open to international trade, whenever there is an absolute advantage in the production of a product. The theory of comparative advantages stated by Ricardo (1817) eliminates conditions for the specialization of countries intervening in international trade flows. In terms of the cost and relative price of the two products traded between the two countries, the Ricardian model can be regarded as a barter model. Because they are different, countries believe that it is worth exchanging with each other: each of them is also able to regain some benefit from this mutual exchange and this mutual specialization in one of the two productions. In other words, exchange reflects a mutual benefit, which means that there is no competition among stakeholders, because each country specializes in producing goods that have a comparative advantage over other countries. Since the profits of one do not result from the cost of the other, two countries participating in the exchange will not compete with each other, whether from absolute advantage theory or comparative advantage theory. The second view reviews the two strongest criticisms of national competitiveness: on the one hand, Porter (1990), and on the other, Krugman (1994). Porter (1990) believes that national competitiveness is an indefinite concept, and only economic prosperity is meaningful at the national level. Krugman (1994; 1996a) described the country's competitiveness as a "dangerous obsession ». Krugman emphasized that this concept lacks a concrete and consistent definition.

Many tools have been used in empirical work to measure competitiveness. However, these metrics have changed from one analysis level to another. At the national level, the assessment of competitiveness mainly focuses on indicators related to international trade and the growth of national factor productivity. At sector level, trade indicators are the most commonly used indicators in empirical studies ${ }^{4}$. Finally, at the microeconomic level, two types of tools are the center of company competitiveness analysis. We cite measures related to market share and measures related to profit ${ }^{5}$. In the following, the focus will be on measurement tools related to international, national, and sectoral levels.

Competitiveness lies in taking advantage of the advantages brought about by globalization. This is due to the intensification of world trade flows and the emergence of new competitors who can quickly drive established leaders out of the world market. Therefore, each country needs to defend its competitiveness in the domestic or international market in order to restore new market share, attract

\footnotetext{
3 Krugman (1994), "Competitiveness: A dangerous obsession". Foreign Affairs.

${ }^{4}$ Trade-related measures are also based on comparative advantage theory. Indeed, the existence of comparative advantage leads to cost advantage, therefore a specialization in this product, which can explain its important share in exports.

${ }^{5}$ Considering the limitations of these two performance indicators of company, they are not common in the literature. Lachaal, L. " La compétitivité: Concepts, définitions et applications ", 2001, PP :29-36
} 
more investment, help its companies and its industries to generate more income, stimulate innovation and create jobs opportunities to enhance its competitiveness and increase its overall wealth. These improvements in competitiveness have driven stronger economic growth in the future and promoted the integration of countries into the world market. In this regard, the OECD (1992) suggested: "A country's competitiveness must simultaneously translate into income growth, the same level of employment as the direct competitors, and acceptable status in terms of the balance of payments."

Regarding these definitions, we conclude that national competitiveness is a complex, dynamic and relative concept. Although this is a topic that some economists are concerned about, it is still not really clear today. However, competitiveness is more of a measure of results: it means more or less competitive than the other party in order to respond to increasing competitive pressure in a changing environment.

\section{INTERNATIONAL TRADE IN MOROCCO: A SECTORAL ANALYSIS}

In a process of reorganization on a global scale, Morocco has been involved in the process of integration into the international trading system for several years. In order to successfully integrate, Morocco has signed a number of sector strategies to pursue economic diversification policy and open to the north and south. We can foresee that this opening will have an impact on the structural transformation of the production structure and the have of resources and geographical factors. Therefore, Morocco will be required to accept the major challenge of accelerating its structural transformation process, which involves the development of productive, competitive and job creation structure.

Over the past two decades, the evolution of Morocco 's international trade began with major changes in the export structure and the improvement of its quality and technological content, which affected their competitiveness. In fact, Morocco has an open economic system, and foreign trade in goods accounted for $67 \%$ of GDP in 2018. In addition, the export structure has undergone major changes, shifting to emerging industrial branches with high added value, and better adapted to the scale of world demand. As for the traditional sectors, they have declined, this change can be explained by the focus of Moroccan industry to the global trade, such as the automotive sector, aeronautic, offshoring.

Indeed, the automotive industry was Morocco 's largest export industry in 2018, and exports increased by $10 \%$ between 2017 and 2018. As for agriculture and the agri-food industry, this flagship export supply sector remains on the export podium in 2018 with a share of $21 \%$ as well as a significant contribution to economic growth, the textile sector as well as the aeronautic sector are respectively 13 , $75 \%$ and $5.35 \%$ of Moroccan exports. On the other hand, an analysis of the flow of Moroccan goods shows that despite Morocco's growing openness to the world economy, they remain concentrated in the European Union, which accounts for two-thirds of its exports. Spain and France are still major partners, with a share of $23 \%$ and $21 \%$ in 2018 . At the same time, Moroccan commodities are supplied to multiple markets outside Europe, especially India, Brazil and the United States, with export value shares of approximately 3\%, 2\% and 4\% in 2018.

Morocco has taken a number of actions in various sectors to diversify and strengthen its competitive potential in exports. The combined results of these efforts are remarkable, except that the development speed and added value of each sector are different, otherwise it is necessary to find the root of this significant progress, and therefore need to analyze the competitiveness of Moroccan economy in order to detect the flagship sectors with a large contribution in exports.

Understanding national competitiveness requires analysis of trade specialization to determine branches or sectors where Morocco has a comparative advantage in trade with other countries in the world. Through this specialization, the country's potential can be revealed, enabling it to direct its strategic direction to promising industries with high added value.

The data used in this analysis comes from the United Nations database (UN Comtrade Data base). Balassa 's comparative index is calculated for different parts of Morocco based on the Standard 
International Trade Classification (SITC) ${ }^{6}$ Revision3. Then, apply this global approach to each competitive sector and break it down to show competing products.

Table 1: Sectors and products with comparative advantage for Morocco

\begin{tabular}{|c|c|c|}
\hline Sector & Products & $\begin{array}{l}\text { Revealed Comparative } \\
\text { Advantage Index }{ }^{7} \text { (Year } \\
\text { 2018) }\end{array}$ \\
\hline \multirow{4}{*}{ Food and live animals } & $\begin{array}{l}\text { Fish, crustaceans, molluscs and } \\
\text { preparations thereof. }\end{array}$ & 9,85 \\
\hline & - Vegetables and fruits. & 7,19 \\
\hline & - Sugar, sugar preparations and honey. & 2,83 \\
\hline & $\begin{array}{l}\text { Feedstuff for animals (excluding } \\
\text { unmilled cereals). }\end{array}$ & 1,16 \\
\hline \multirow[b]{2}{*}{$\begin{array}{l}\text { Crude materials, inedible, except } \\
\text { fuels }\end{array}$} & - $\quad$ Crude fertilizers and crude minerals. & 17,92 \\
\hline & - Crude animal and vegetable materials. & 1,07 \\
\hline \multirow[b]{2}{*}{$\begin{array}{c}\text { Animal and vegetable oils, fats and } \\
\text { waxes }\end{array}$} & - Animal oils and fats. & 8,61 \\
\hline & $\begin{array}{l}\text { Fixed vegetable oils and fats, crude, } \\
\text { refined or fractionated. }\end{array}$ & 1,35 \\
\hline \multirow{2}{*}{ Chemicals and related products } & - Inorganic chemicals. & 8,99 \\
\hline & - $\quad$ Fertilizers other than group 272. & 37,31 \\
\hline \multirow{3}{*}{$\begin{array}{l}\text { Miscellaneous manufactured } \\
\text { articles }\end{array}$} & $\begin{array}{l}\text { - Articles of apparel \& clothing } \\
\text { accessories. }\end{array}$ & 5,09 \\
\hline & - Footwear. & 1,67 \\
\hline & - Furniture and parts thereof. & 1,14 \\
\hline
\end{tabular}

Source: UN-Comtrade data, author's calculation

In order to understand the potential of Moroccan products in the world market, we use the export potential value indicator of products that Morocco has regularly exported and whose export potential is at least US \$200,000 (see Appendix 2). Therefore, the export potential of Morocco lies in the families of several products, as shown in Figure 1 below:

\footnotetext{
6 The application of the SITC revision3 is justified by the harmonization of its sections and the unification of the products of each section between Morocco and partner countries.

${ }^{7}$ «The revealed comparative advantage (RCA) is based on Ricardian trade theory, according to which trade flows between countries are regulated by their relative differences in productivity. Although these performance differences are difficult to observe, the RCA measure can easily be calculated using commercial data to "reveal" these differences. This measure can be used to provide a general indication and first approximation of the competitive strength of a country's export. It should be noted that national measures affecting competitiveness, such as customs duties, non-tariff measures, subsidies and others are not taken into account». ONU
} 
Figure 1: The top 10 Morocco's products with high potential

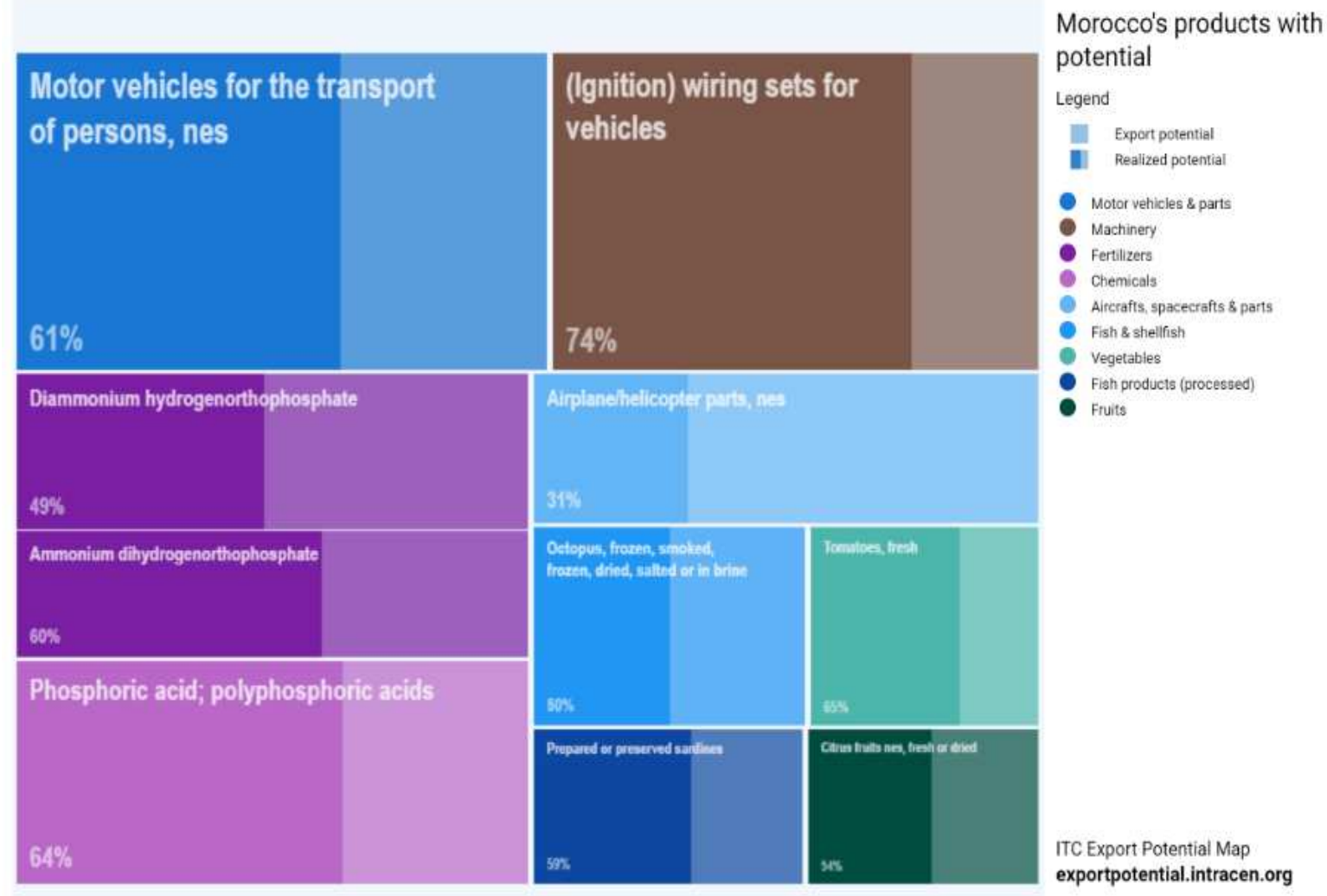

Source: Export Potentiel Map able below shows Morocco 's export potential, current export and untapped potential, sorted by market and descending order.

Table 2: Morocco's export potential by market

\begin{tabular}{|c|c|c|c|c|}
\hline Market & Regional market & Export potential & $\begin{array}{l}\text { Current } \\
\text { exports }\end{array}$ & $\begin{array}{l}\text { Unexploited } \\
\text { Potential }\end{array}$ \\
\hline France & Developed countries & $\$ 6$ Mds & \$5.4 Mds & $\$ 2.2 \mathrm{Mds}$ \\
\hline Spain & Developed countries & $\$ 5.5 \mathrm{Mds}$ & $\$ 6.2 \mathrm{Mds}$ & \$1.4Mds \\
\hline United States of America & Developed countries & $\$ 1.5 \mathrm{Mds}$ & \$1.0Mds & \$1.0Mds \\
\hline Germany & Developed countries & \$1.3Mds & $\$ 920.7 \mathrm{Mns}$ & $\$ 654.8 \mathrm{Mns}$ \\
\hline India & Developing countries & \$1.3Mds & $\$ 716.3 \mathrm{Mns}$ & $\$ 588.2 \mathrm{Mns}$ \\
\hline Italia & Developed countries & \$1.3Mds & \$1.0Mds & $\$ 662.0 \mathrm{Mns}$ \\
\hline Brazil & Developing countries & \$1.1Mds & 683.3Mns & $\$ 485.6 \mathrm{Mns}$ \\
\hline United Kingdom & Developed countries & \$1.1Mds & 771.1Mns & $\$ 507.1 \mathrm{Mns}$ \\
\hline Turkey & Developing countries & \$877.0Mns & 587.1Mns & \$497.0Mns \\
\hline Netherlands & Developed countries & $\$ 767.7 \mathrm{Mns}$ & 493.8Mns & \$451.1Mns \\
\hline
\end{tabular}




\begin{tabular}{|c|l|l|l|l|}
\hline Russian Federation & Developing countries & $\mathbf{\$ 6 6 3 . 1 M n s}$ & $\mathbf{3 7 4 . 4 M n s}$ & $\mathbf{\$ 3 0 9 . 2 \mathrm { Mns }}$ \\
\hline China & Developing countries & $\mathbf{\$ 6 0 9 . 1 M n s}$ & $\mathbf{2 5 3 . 1 M n s}$ & $\mathbf{\$ 4 9 5 . 8 M n s}$ \\
\hline
\end{tabular}

Source : Export Potentiel Map

\section{ESTIMATED MODELS, RESULTS AND DISCUSSIONS}

\section{Estimated models}

In empirical literature, the most common models for modeling export volume are variants of the imperfect substitute model, whose theoretical basis goes back to Armington (1969).

This model combines export trends with a number of variables. These variables are of two types. The one reflecting the price effect and the one reflecting the volume effect. The price effect is a variable which takes into account price differences between the local economy and the economy of the partner countries. In fact, prices affect choices, so to understand the export volume, prices must be considered. As for the quantity effect, it illustrates the quantity of demand in the Moroccan market.

Conceptually, the model is based on two main assumptions:

- H1: Homogeneity and incomplete substitution of products from the same sector in the same country.

- H2: independence of choice between product categories, which means that the choice of product by the consumer in a given market did not follow purchases in third markets.

The resulting demand functions can be explained by the total income, the foreign price of the traded commodity, and its domestic price equivalent. In addition, consumers will never suffer from the illusion of currency, which will lead to the homogeneity of the demand function. Therefore, the function is modeled by the following equation:

$$
\mathrm{P}_{\mathrm{X}} \mathrm{X}=\mathrm{g}\left(\mathrm{wd}, \mathrm{p}_{\mathrm{X}}, \mathrm{p}^{*}\right) \text {, avec } \frac{\partial_{\mathrm{g}}}{\partial \mathrm{wd}}+\frac{\partial_{\mathrm{g}}}{\partial \mathrm{p}_{\mathrm{X}}}+\frac{\partial_{\mathrm{g}}}{\partial \mathrm{p}^{*}}=1 \quad \text { Eq. (01) }
$$

$\mathrm{X}$ represents the export demand in terms of volume, wd the demand for the rest of the world directed to the country concerned, $\mathrm{p}_{\mathrm{x}}$ the price of the exported product, and $\mathrm{p}^{*}$ its price abroad. The homogeneity of degree 1 allows to specify the volume export function in the following form:

$$
\mathrm{X}=\mathrm{g}\left(\mathrm{wdr}, \mathrm{rpr}_{\mathrm{x}}\right) \quad \text { Eq. (01.A) }
$$

wdr represents real-world demand for the country concerned and $\operatorname{rpr}_{\mathrm{x}}$ the term of price competitiveness, i.e. the relative price index. The model of imperfect substitutes assumes a multiplicative relationship of this type:

$$
\mathrm{X}=\mathrm{A}_{\mathrm{x}}(\mathrm{wdr})^{\alpha}(\mathrm{rpr})^{\beta} \quad \text { Eq. (01.B) }
$$

The log-linearization of this relationship makes it possible to obtain the long-term export equation of a country, which directly correlates the export volume with the global demand addressed and the relative price of exports. The formula is as follows:

$$
\log (\mathrm{X})=\mathrm{A}_{\mathrm{X}}+\alpha \ln (\mathrm{wDr})+\beta \ln (\mathrm{rPr})+\varepsilon \quad \text { Eq. (01.C) }
$$

Where $\alpha$ and $\beta$ represent the demand elasticity and price elasticity of exports, respectively. This equation represents the traditional "Armington" export equation, which will form the basis of our future estimates.

Following the Amington model, several models have been developed with the latest changes in the global goods and services market. Most of these models are used in specific environments according to the purpose of economic analysis. Within this framework, some studies aimed at studying export competitiveness use the Amington model and add other explanatory variables to the model.

Indeed, we have seen that with the intensification of economic opening and the resulting fierce competition, exports are not just explained by demand and price effects. Other factors also play a role 
and are used in new international trade theories. These are variables of quality, difference, proximity and other commodities. These models are called Armington models augmented.

Consistent with previous work ${ }^{8}$ on the differences in trade performance of countries, we evaluated the development of Moroccan exports using traditional augmented trade equations, and we focused on the measurement of price competitiveness and cost competitiveness.

Therefore, we will estimate Armington's export equation and gradually enrich it with traditional price and cost competitiveness measures.

The global equation in log-linear form is as follows:

- Price competitiveness:

$\ln (\mathrm{EXP})=\ln (\mathrm{A})+\alpha \ln (\mathrm{WD})+\beta \ln (\mathrm{REER})+\gamma \ln (T E)+\delta \ln (W O)+\varphi \ln (R I N V)+\varepsilon$ Eq. (02.)

- Cost competitiveness:

$$
\ln (\mathrm{EXP})=\ln (\mathrm{A})+\alpha \ln (\mathrm{WD})+\beta \ln (\mathrm{ULC})+\delta \ln (W O)+\varphi \ln (R I N V)+\varepsilon
$$

Eq. (03.)

With:

EXP , Moroccan exports;

WD, The index of world demand for Morocco;

REER, The real effective exchange rate;

TE , Terms of trade;

WO, Morocco's openness index;

RINV,The rate of Investment;

ULC, Unit labor cost ${ }^{9}$.

In this section, we propose an empirical estimation of the determinants of Moroccan external competitiveness using augmented export equations, the variables used are selected based on their importance in Morocco's foreign trade and the availability of data needed to test the model. The data refer to the period 1988-2017. Before the estimation, we applied log transformation to all series. Indeed, our explained variable exports are expressed in quantities, while our explanatory variables are rates or indices.

Therefore, there is a difference between the explained values and the explanatory values. Logarithm helps reduce these differences. In addition, since the logarithm will be based on the percentage, the logarithm is helpful for interpretations.

\section{Results and discussions}

\subsection{Price competitiveness}

The following introduces our estimate of the price competitiveness of $\mathrm{R}$ software. It should be remembered that we must estimate VECM with the specification "Absence of a linear trend in the series, but there are constants in the cointegration relationship" and two cointegration relationships.

\footnotetext{
8 In this work, we mainly use Raphaël Chiappini's article. (2011). "Comment mesurer la compétitivité structurelle des pays dans les équations d'exportation ? " Economic news, Volume 87, Issue 1, pages 31-57.

${ }^{9}$ For a detailed presentation of the variables, see Appendix 3.
} 
Table 3: Results of estimates with price competitiveness indicators

\begin{tabular}{|c|c|}
\hline \multicolumn{2}{|c|}{ Long term equations } \\
\hline Cointegration Eq 1 & Cointegration Eq 2 \\
\hline $\begin{aligned} E X P . l 3= & -8,62 *(T E . l 3)+16,32 * \\
(W O . l 3)-18,05 *(R I N V . l 3)-0,32 * & (W D . l 3)+29,73\end{aligned}$ & $\begin{array}{c}\text { REER.l3 }=0,55 *(\text { TE.l3 })-0,5 * \\
(\text { WO.l3 })+(0,11 *(\text { RINV.l3 })-0,05 * \\
(\text { WD.l3 })+1,57\end{array}$ \\
\hline \multicolumn{2}{|c|}{ Short term equation } \\
\hline Variables & Estimated coefficients \\
\hline Error correction term 1 & $-0,2956 * *$ \\
\hline Error correction term 2 & $-4,0365 * *$ \\
\hline$\Delta E X P . l 1$ & $-0,3680$ \\
\hline$\triangle R E E R . l 1$ & 0,8019 \\
\hline$\Delta T E . l 1$ & $-1,7343 * *$ \\
\hline$\Delta W 0 . l 1$ & $2,0522 * *$ \\
\hline$\Delta R I N V . l 1$ & $-0,6528$ \\
\hline$\Delta W D . l 1$ & $-0,0614$ \\
\hline$\Delta E X P . l 2$ & 0,2814 \\
\hline$\triangle R E E R . l 2$ & $-4,8530 * *$ \\
\hline$\Delta T E . l 2$ & 0,5043 \\
\hline$\Delta W 0 . l 2$ & $2,9841 * *$ \\
\hline$\Delta R I N V . l 2$ & $-2,6637 *$ \\
\hline$\Delta W D . l 2$ & $-0,2977 * * *$ \\
\hline Number of observations & 30 \\
\hline $\mathrm{R}^{2}$ Adjusted & 0,65 \\
\hline Box-pierce test & 0,974 \\
\hline
\end{tabular}

Note: *,**,*** significant to $10 \%, 5 \%, 1 \%$

Since the aim of this research is to study the determinants of Morocco's external competitiveness, we will focus only on the export equation. The VECM model allows us to analyze short- and long-term relationships at the same time. The full VECM equation for our research variable (Export) is therefore as follows ${ }^{10}$ :

$$
\begin{aligned}
\Delta E X P=-0,29 & ((E X P . l 3)+(8,62 * T E . l 3)-(16,32 * W O . l 3)+(18,05 * R I N V . l 3) \\
& +(0,32 * W D . l 3)-29,73)-4,03((R E E R . l 3)-(0,55 * T E . l 3)+(0,5 \\
& * W 0 . l 3)-(0,11 * R I N V . l 3)+(0,05 * W D . l 3)-1,57)-1,73(\Delta T E . l 1) \\
& +2,05(\Delta W 0 . l 1)-4,85(\Delta R E E R . l 2)+2,98(\Delta W 0 . l 2)-2,665(\Delta R I N V . l 2) \\
& -0,29(\Delta W D . l 2)
\end{aligned}
$$

10 The long-term relationship is represented by the level variables, as long as the short-term relationship is represented by the difference variables. 


\subsubsection{Validity of model}

We start with the coefficient of determination. In fact, it allows us to assess the quality of our model. The coefficient of determination of the VECM model for exports is 0.65 . This means that $65 \%$ of the total variance was explained by our model. Our model can be considered valid.

Therefore, our variables are globally significant. The coefficients of the two co-integration relationships are significant and negative (ect $1=-0.29$; ect $2=-4.03$ ). Therefore, the short-term and long-term relationship is confirmed.

We will rely on another test Ljung-Box to verify the validity of our model. By using Ljung-Box's Q statistic, the test can verify that the residue generated by each of the two equations is white noise. In fact, the Ljung-Box Q statistic with a delay of $h=15$ confirms that there is no autocorrelation, and the test probability of $h=15$ is $0.97>0.05$, thus accepting the null hypothesis of white noise.

\subsubsection{Price effect}

According to the traditional results and considering the results of the VECM model, the variable real effective exchange rate showed significant and negative changes. In the short term, a $1 \%$ increase in the real effective exchange rate will cause exports to fall by $-4.85 \%$ in the next period. The effective exchange rate has a negative impact on exports. This result is consistent with economic theory. Indeed, an increase in the exchange rate may have a dual impact on the economy, firstly, exported goods and services become relatively more expensive, which makes it difficult for Morocco to maintain its competitive gains, which is why consumers of partner countries will consume less and the volume of exports will decrease. Then, as exports fell, national supply increased in the subsequent period, so prices fell relatively, which may increase exports. As a result, Morocco 's external competitiveness is relatively sensitive to variations in prices and exchange rates.

On the other hand, estimates show that the variable terms of $\operatorname{trade}^{11}$ is negative and significant, which means that in the short term, a change of $1 \%$ in the terms of trade leads to a $1.73 \%$ decrease in exports. In other words, an improvement in terms of trade by $1 \%$ also means a deterioration in the price competitiveness of Moroccan exports on international markets by $1.73 \%$. On the contrary, a decline in terms of trade means an increase in price competitiveness. In the long run, exports are more sensitive to changes in terms of trade. The results obtained from this variable are consistent with theoretical and empirical contributions found in previous studies.

\subsection{Cost competitiveness}

The following table lists the results of $\mathrm{R}$ software's estimation of our cost competitiveness. As with previous estimates, VECM's estimation specification is "Absence of a linear trend in the series, but there is a constant in the cointegration relationship" and two cointegration relationships.

Table 4: Results of estimates with cost competitiveness indicator

\begin{tabular}{|c|c|}
\hline \multicolumn{2}{|c|}{ Long term equations } \\
\hline Cointegration Eq 1 & Cointegration Eq 2 \\
\hline $\begin{array}{l}E X P . l 2=4,53 *(R I N V . l 2)+4,05 * \\
(U L C . l 2)-0,12 *(R I N V . l 3)-2,99\end{array}$ & $\begin{array}{c}\text { WO.l2 }=-7,41 *(\text { RINV.l2 })-7,39 * \\
(\text { ULC.l2 })+0,22 *(\text { WD.l2 })+20,68\end{array}$ \\
\hline \multicolumn{2}{|c|}{ Short term equation } \\
\hline Variables & Estimated coefficients \\
\hline
\end{tabular}

\footnotetext{
11 " Terms of trade are the ratio for a given product between the export price index and the import price index, with these indices expressed in relation to the same base year. A $1 \%$ improvement in the terms of trade means that the growth in export prices is $1 \%$ higher than that of import prices. It also signifies a deterioration in price-competitiveness. Conversely, a drop in the terms of trade indicates an improvement in price-competitiveness. This ratio can be calculated by product, for a set of products, or globally. ". INSEE
} 


\begin{tabular}{|c|c|}
\hline Error correction term $\mathbf{1}$ & $-0,3504^{* *}$ \\
\hline Error correction term $\boldsymbol{2}$ & $-0,2176^{* *}$ \\
\hline$\Delta \boldsymbol{E} \boldsymbol{X P} . \boldsymbol{l 1}$ & $-1,3444$ \\
$\Delta \boldsymbol{W} \boldsymbol{O} . \boldsymbol{l 1}$ & $-0,2690$ \\
$\Delta \boldsymbol{R} \boldsymbol{I} \boldsymbol{N} \boldsymbol{V} . \boldsymbol{l 1}$ & $0,1110^{* *}$ \\
$\Delta \boldsymbol{U} \boldsymbol{L} \boldsymbol{C} . \boldsymbol{l 1}$ & $0,0774^{* *}$ \\
$\Delta \boldsymbol{W D} . \boldsymbol{l 1}$ & $0,0090^{* * *}$ \\
\hline $\mathrm{R}^{2}$ Adjusted & 0,69 \\
Test de Box-pierce & 0,968 \\
\hline
\end{tabular}

Note : *,**, *** : significant to $10 \%, 5 \%, 1 \%$

The full VECM equation for our research variable (Export) is as follows:

$$
\begin{aligned}
\Delta E X P=-0,35 & ((E X P . l 2)-(4,53 * R I N V . l 2)-(4,05 * U L C . l 2)+(0,12 * R I N V . l 3) \\
& +2,99)-0,21((W 0 . l 2)+(7,41 * W I N V . l 2)+(7,39 * U L C . l 2) \\
& -(0,22 * W D . l 2)-20,68)-1,34(\Delta E X P . l 1)-0,26(\Delta W 0 . l 1) \\
& +0,11(\Delta R I N V . l 1)+0,07(\Delta U L C . l 1)
\end{aligned}
$$

\subsubsection{Validity of model}

We start with the coefficient of determination. In fact, it allows us to assess the quality of our model's. The coefficient of determination of the VECM model for exports is 0.69 . Our model can be considered valid.

Therefore, our variables are globally significant. The coefficients of the two cointegration relationships are significant and negative (ect $1=-0.35$; ect $2=-0.21$ ). Therefore, the short-term and long-term relationship is confirmed.

On the other hand, the Ljung-Box $\mathrm{Q}$ statistic with delay $\mathrm{h}=10$ confirms that there is no autocorrelation. In fact, the test probability of $h=10$ is $0.96>0.05$, so the null hypothesis of white noise is accepted.

\subsubsection{Production cost and quality effect}

In explaining exports, unit labor cost is also important. In the short term, a unit labor cost increase of $1 \%$ will increase the export growth rate slightly by $0.07 \%$ over the next period of time. This result is not in line with the theory that the higher the unit labor cost, the higher will be the cost of goods production, and therefore the prices charged by producers will be high, and therefore locally exported products will be lower competitive on the international market.

The variable that captures quality is the investment rate. We note that this variable is significant in our VECM model. It can be seen that the investment rate will affect exports in the short term. As we expected, the $1 \%$ increase in the investment rate results in a $0.11 \%$ increase in exports in the next period. Therefore, Morocco 's exports are not very sensitive to changes in short-term investment rates. However, in the long term, investments have a much larger impact on exports, in fact a $1 \%$ increase means a $4.53 \%$ increase in exports, which is in line with the theory. 


\section{CONCLUSION}

The study attempts to examine the impact of competitive factors on exports. To this end, we estimate the Armington model plus prices, cost and quality variables. We used two models, the first captures the price effect and the second captures the cost and quality effect. Indeed, the results of these estimates allow us to clarify certain aspects. On the one hand, Morocco's exports are sensitive to price factors (real effective exchange rate, terms of trade) and competition effect. However, they are less sensitive to short-term investments than to long-term ones. Indeed, an increase in the real effective exchange rate will reduce exports. As for investment, it has a positive impact, but in small proportions.

On the other hand, according to the comparative advantage indicator, we note that Morocco has an advantage especially with regard to chemicals and related products, clothing and food products compared to other countries. However, the potential of our export on the world market lies mainly in the following product families: Fertilizers, machines, chemicals as well as vehicles and car parts. The opening of Morocco and the signing of a series of free trade agreements have changed the export structure in recent years in favor of emerging industrial branches with high value added and better positioned to the scale of global demand. The positioning of the Moroccan industry in global professional fields such as automobile manufacturing and aviation can explain this change.

In addition, the use of disaggregated data may lead better results in modeling. In fact, Morocco's export sectors is positioned differently globallyour, so we can assume that trade liberalization will not have the same impact on all sectors ${ }^{12}$, then the external competitiveness of different sectors will be different. In addition, the use of non-price competitive indicators such as human capital and institutional quality is one of the ways to conduct further research on this topic, which will allow us to highlight other variables explaining the trade performance of Morocco in the recent period.

12 Milton, S. Siddique, M. A. B. (2014). "Trade Creation and Diversion Under the Thailand Australia Free Trade Agreement 


\section{REFERENCES}

[1] Abdmoulah, Walid, Belkacem Laabas (2010). Assessment of Arab export competitiveness in international markets using trade indicators, API/WPS 1010.

[2] Aglietta.M, Coudert.V, Baulant.C (1999). Compétitivité et régime d'échange en Europe centrale, Revue économique, volume 50, nº 6 , pp :1221-1236.

[3] Ana.C, António.D (2017). The impact of the Chinese exchange policy on foreign trade with the European Union. Brazilian Journal of Political Economy, vol. 37, no 4 (149), pp. 870-893.

[4] Armington, P. (1969). A Theory of Demand for Products Distinguished by Place of Production ", International Monetary Fund Staff Papers, XVI: 159-178.

[5] Chiappini, R. (2011). Comment mesurer la compétitivité structurelle des pays dans les équations d'exportation, L'Actualité économique, 31-57.

[6] Cyrielle Gaglio (2017). Compétitivité, sophistication et espace-produit. Une application aux exportations françaises. Economies et finances, Thèse de doctorat. Université Côte d'Azur.

[7] Direction des Etudes et des Prévisions Financières (2018). Rapport d'activité, Ministère de l'Economie et des Finances, pp : 26-30.

[8] Erkel-Rousse Hélène (1992). Les performances extérieures de la France et de l'Allemagne : l'effet de l'investissement sur la compétitivité. Economie et statistique, n²53, pp. 35-47.

[9] G. I. P. Ottaviano (2011). New economic geography: Firm heterogeneity and agglomeration economics. Journal of Economic Geography.

[10] Gaussens, O. \& Phan, D. L. (1986). Avantage comparatif et performance dans le commerce international des produits différenciés. L'Actualité économique, 62 (4), 535-556.

[11] Hélène Hamisultane (2002). Econométrie Des Séries Temporelles. Licence. France. 2002. cel- 01261174.

[12] Hélène Hamisultane (2002). Modele à correction d'erreur (Mce) Et Appplications. Master. France. 2002. cel-01261167.

[13] Laboratoire d'Economie Appliquée- Rabat (2017). Equilibres Externes, Compétitivité et Processus de Transformation Structurelle de l'Economie Marocaine, OCP Policy Center.

[14] Lachaal, L (2001). La compétitivité : Concepts, définitions et applications. CIHEAM Cahiers Options Méditerranéennes; n. 57, pp : :29-36.

[15] M. Porter (1990). The competitive advantage of nations. New-York, The Free Press.

[16] Mankan Mohammed KONE (2012). Effets des facteurs de compétitivité sur les performances àccl'exportation du secteur industriel marocain, INSEA.

[17] MELITZ, M. (2003). The Impact of Trade on Intra-Industry Reallocations and Aggregate Industry Productivity, Econometrica, 76(1): 1695-1725.

[18] Milton, S., \& Siddique, M. A. B. (2014). Trade Creation and Diversion Under the Thailand Australia Free Trade Agreement (TAFTA), No. 14-26.

[19] OCDE (1992). La technologie et l'économie : Les relations déterminantes. Paris, Les Editions de l'OCDE

[20] P. R. Krugman (1981). Intra industry specialization and the gains from trade. Journal of Political Economy, (89).

[21] P. R. Krugman (1991). Increasing returns and economic geography. Journal of Political Economy, (99). 
[22] P. R. Krugman (1994). Competitiveness: A dangerous obsession. Foreign Affairs.

[23] P. R. Krugman (1996a). Making sense of the competitiveness debate. Oxford Review of Economic Policy.

[24] R. E. Baldwin et T. Okubo (2006). Heterogeneous firms, agglomeration and economic geography: Spatial selection and sorting. Journal of EconomicGeography.

[25] R. Hausmann et D. Rodrik (2003). Economic development as self-discovery. Journal of Development Economics.

[26] Raphaël Chiappini (2011). Compétitivité, stratégies et performances commerciales : une application à la zone euro. Thèse de doctorat. Université de Bordeaux, département : Entreprise, société et économie.

[27] Sargsyan. A (2018). Export competitiveness: Assessment through the Balassa index (the case of Armenia). Preprints.

[28] Walter Paternesi Meloni (2018). Italy's Price Competitiveness: An Empirical Assessment Through Export Elasticities. Ital Econ J 4, 421-462.

[29] Wondemu, Kifle and Potts, David, (2016). The Impact of the real exchange rate changes /on export performance in Tanzania and Ethiopia, Working Paper Series $\mathrm{N}^{\circ} 240$, African Development Bank, Côte d'Ivoire.

[30] Yannick Bineau, Bernard Dupon (2004). Taux de change et soutenabilité extérieure. Un Modèle dynamique, Revue économique, Vo: 55, pp : 675-688. 


\section{APPENDICES}

\section{Appendix A: Detailed methodology of the Balassa Revealed Comparative Advantage Index}

The calculation of the BRCA indicator is mainly based on the share of exports:

i. $\quad$ Share in the export market $\left(E X P_{p}\right): E X P_{p}=\left(\frac{X_{i k}}{X_{i w}}\right)$, with $: X_{i k}=$ value of export from country $\mathrm{k}$ for sector i $X_{i w}=$ value of global sector exports .

ii. Balassa Revealed Comparative Advantage Index: $I A C R B_{i k}=\left(\frac{X_{i k}}{X_{i w}}\right) /\left(\frac{X_{k}}{X_{w}}\right)$.

with: $X_{k}=$ value of exports from all sectors of country $\mathrm{k} ; X_{w}=$ value of world exports from all sectors. The share of exports from country $\mathrm{k}$ in world exports is used to normalize this index. If the index is greater than 1, the country is considered to be specialized in the industry (comparative advantage in the industry) because it is relatively more exporting than the reference area. Of course, the country's specialization is even stronger because the index is higher than 1. On the contrary, if the indicator is less than 1 , the country is not specialized in the branch (comparative disadvantage). The disadvantage is all the greater when the indicator approaches 0 .

\section{Appendix B : Detailed methodology of the Export Potential Indicator ${ }^{13}$}

The export potential indicator is the export value of the potential, for products already regularly exported by Morocco, for which the export potential is at least $\$ 200,000$. Export potential is not the maximum value but a reasonable export value to the market, taking into account the performance of the country and domestic demand as well as market access conditions.

Estimating export potential includes first forecasting the demand for imports of each product on each market based on current demand, population growth and expected GDP per capita growth. Current trade may be lower than potential, which indicates that it is possible to increase exports to related markets, but it may also be higher than this potential, which means that new competitors may threaten the current position of exporters in these markets.

$$
E P I_{i j k}=\text { Exp. Supply } y_{i k} \times \frac{x_{i j}}{\sum_{k} \text { Supply }_{i k} \times M A_{i j k} \times m_{j k}} \times M A_{i j k} \times \text { Exp. }_{j k} \quad \text { Eq. (B1.1) }
$$

- $\quad x=$ exports ( $m=$ imports) of the country $i$ (market $j$ ) for the product $k$.

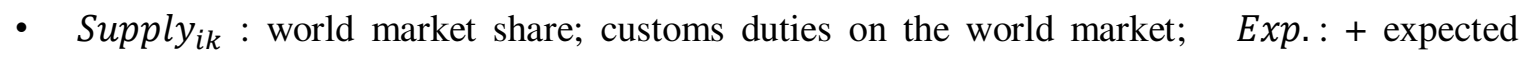
growth of the exporter.

- Easiness $_{i j}=\frac{x_{i j}}{\sum_{k} \text { MShare }_{i k} \times m_{j k}}$ is the ratio between the current value exported to the market $j$ and what it would be if the country $i$ had the same market share in this market as in globally.

- $\frac{x_{i j}}{\sum_{k} \text { Supply }_{i k} \times M A_{i j k} \times m_{j k}}$ Adjustment of bilateral trade to take into account the complementarity between supply and demand.

- $\quad M A_{i j k}$ : market access : price preference and product sensitivity over distance;

- $\quad m_{j k}$ : value demand; Exp. : + + demographic growth and expected growth of GDP per capita (taking into account income elasticity).

By combining export performance, ease of export and demand, we obtain:

- Export potential:

$$
E P I_{i j k}=\text { Supply }_{i k} \times \text { Easiness }_{i j} \times \text { Demand }_{i j k} \quad \text { Eq. (B1.2) }
$$

- Unrealized export potential :

$$
\text { Unused potential }_{i j k}=\max \left(E P I_{i j k}-x_{i j k} ; 0\right) \quad \text { Eq. (B1.3) }
$$

\footnotetext{
${ }^{13}$ Export Potentiel Map, International Trade Centre.
} 
The existence of an unrealized export potential can be the consequence of several reasons:

- Non-tariff barriers;

- Positioning in quality or price that does not correspond to market demand;

- Sector made up of a small number of large companies with their own strategy;

- Export potential too low to justify the establishment of a commercial relationship;

- Absence of market analysis: commercial transaction controlled by the buyer.

Appendix C: Data source

Table C.1: Results of estimates with price competitiveness indicators

\begin{tabular}{|c|c|}
\hline Variable & Source \\
\hline Exports / Imports & WTO \\
\hline Real Effective Exchange Rate & World Bank \\
\hline $\begin{array}{c}\text { World demand index addressed to } \\
\text { Morocco }\end{array}$ & Ministry of Economy and Finance \\
\hline Terms of trade & Calculated on World Bank data \\
\hline Openness rate & Calculated on World Bank data \\
\hline Investment rate & World Bank \\
\hline Unit labor cost & $\begin{array}{c}\text { Calculated on data from the Ministry of } \\
\text { Economy and Finance }\end{array}$ \\
\hline
\end{tabular}




\section{Figures}

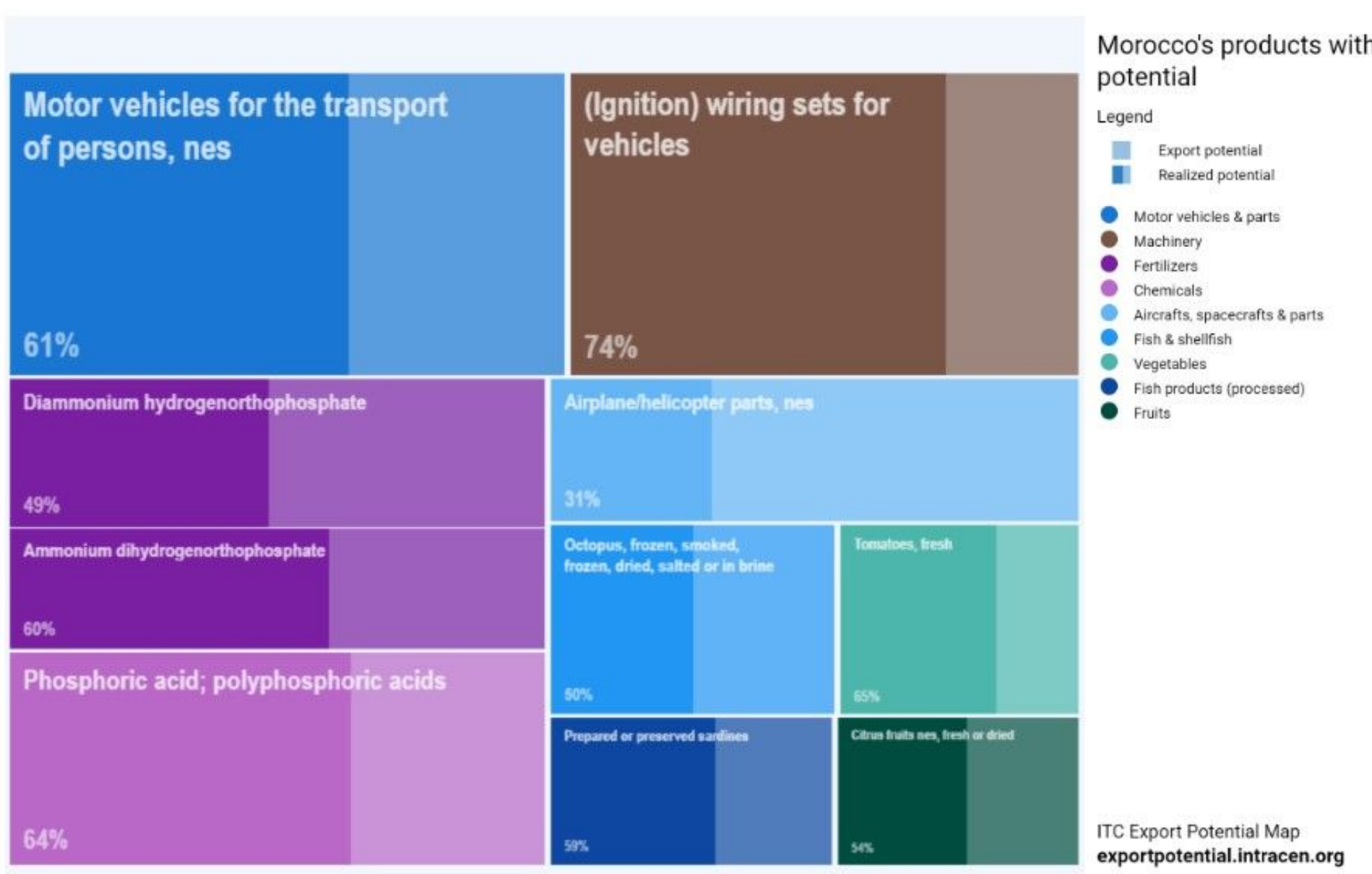

\section{Figure 1}

The top 10 Morocco's products with high potential 